\title{
ASPEK HUKUM KEGIATAN BISNIS DAN FUNGSI PERIZINAN DI INDONESIA DALAM KERANGKA MASYARAKAT EKONOMI ASEAN 2015
}

\author{
Hassanain Haykal \\ email: hassanain.haykal@gmail.com
}

\begin{abstract}
The ASEAN Economic Community (MEA) should be perceived as a joint commitment to establish a (regional) single market within which there would be a free flow of goods and services. This commitment at the regional level inadvertently forces member countries to adjust their national laws and regulations. To be more concrete, simplifying the permit system and bureaucratic streamlining becomes a must. On the other hand, the huge flow of incoming and outgoing trade and services, put pressure to national government to establish a viable control and monitoring system. Reformation of the existing licensing system should be done by identifying overlapping rules and modernizing the government bureaucracy.
\end{abstract}

Keywords:

permits/licensing, Economic ASEAN Community, bureaucratic reform

\begin{abstract}
Abstrak
Kerja sama Masyarakat Ekonomi ASEAN (MEA) merupakan komitmen bersama untuk menjadikan ASEAN sebagai pasar tunggal yang mendorong aliran bebas dari perdagangan dan jasa. Komitmen ini pada tingkat regional memaksa Negara-negara anggota untuk menyelaraskan peraturan perundang-undangan tingkat nasional. Khususnya apa yang dituntut adalah penyederhanaan sistem perizinan serta penataan ulang birokrasi pemerintahan. Pada lain pihak, derasnya arus masuk dan keluarnya barang dan jasa memaksa pemerintah untuk membangun sistem pengawasan yang andal. Reformasi sistem perizinan harus dilakukan dengan mengidentifikasi aturan-aturan yang tumpang tindih dan reformasi birokasi.
\end{abstract}

Kata Kunci:

perizinan, Masyarakat Ekonomi ASEAN, reformasi birokrasi

\section{Pengantar}

Bisnis pada era globalisasi berkembang secara pesat, hal ini ditunjukkan dengan adanya perdagangan bebas di antara negara-negara berkembang maupun negara maju. Munculnya organisasi perdagangan internasional telah mendorong kegiatan bisnis semakin bersaing dan berdaya cipta sehingga mampu memenuhi berbagai kebutuhan masyarakat di seluruh belahan dunia. Namun demikian, 
munculnya persaingan di antara negara-negara berkembang dan maju dapat menimbulkan ketimpangan bagi perdagangan dan jasa di negara lainnya, yang disebabkan belum siapnya negara lain menerima berbagai kebijakan yang bersifat global. Untuk itu, perlu adanya kebijakan regional yang mampu mengantisipasi berbagai ketimpangan yang terjadi, yang bertujuan meningkatkan perekonomian regional, sehingga pada akhirnya mampu bersaing secara global. Salah satu terobosan yang dilakukan dalam rangka peningkatan ekonomi secara regional yaitu dibentuknya Masyarakat Ekonomi ASEAN, selanjutnya disebut MEA.

Kerjasama MEA diharapkan dapat membuka peluang pengembangan dunia investasi melalui pemanfaatan program kerjasama regional, sehingga pengusaha Indonesia dan pengusaha asing dapat bekerja sama. Negara Indonesia memiliki keunggulan komparatif pada sektor berbasis Sumber Daya Alam dan berpeluang besar mengembangkan industri yang potensial di ASEAN sehingga menjadikan Indonesia sebagai basis produksi bukan sebagai basis pemasaran produknya. Konsekuensi dari kesepakatan MEA tersebut berupa aliran bebas barang bagi negara-negara ASEAN, dampak arus bebas jasa, dampak arus bebas investasi, dampak arus tenaga kerja terampil, dan dampak arus bebas modal. Melalui kebijakan yang dikeluarkan oleh Masyarakat Ekonomi ASEAN telah tercipta ruang terbuka bagi para investor untuk menanamkan modalnya di Indonesia. MEA telah mengubah paradigma "competition" menjadi "co-opetition" (Competition dan Cooperation),

Berdasarkan hal tersebut, perlu adanya harmonisasi dan perubahan hukum atas berbagai kebijakan MEA tanpa menghilangkan aspek penting kedaulatan ${ }^{1}$ dari masing-masing negara yang terlibat. Hukum dalam suatu negara

1 Kedaulatan diartikan sebagai "kekuasaan tertinggi" yang menentukan kekuatan dan legitimasi negara dalam menentukan dan menjalankan berbagai kebijakan, lihat Fancis Fukuyama, 2005 hlm. 124. Begitu pula Mac Iver, mengemukakan: "The Ultimate Sovereign. So we shall name the power which ultimately determaines the policy of the state". Jadi menurut Mac Iver, "kedaulatan adalah kekuasaan tertinggi yang akan menentukan kebijakan (policy) dari negara", 
memiliki peran yang sangat penting dalam mengatur berbagai aspek kehidupan masyarakat. Untuk itu, hukum harus berjalan secara dinamis agar mampu menyesuaikan diri dengan berbagai perkembangan yang terjadi, sehingga tujuan hukum sebagaimana dicita-citakan dalam menciptakan ketertiban, kedamaian dan keadilan dapat tercapai.

Salah satu instrumen hukum pengendalian kegiatan bisnis, khususnya dalam lapangan Hukum Administrasi dalam kerangka MEA, adalah aspek perizinan. Izin adalah suatu instrumen pemerintahan yang bersifat yuridis preventif, yang digunakan sebagai sarana hukum administrasi untuk mengendalikan perilaku atau kegiatan masyarakat dengan keharusan memenuhi asas legalitas. Dengan demikian, perizinan hanya dapat diterbitkan atau dikeluarkan oleh pemerintah saja sebagai badan hukum publik. Hal ini menunjukkan bahwa pemerintah berwenang untuk mengatur, mengarahkan, mengendalikan, sekaligus melindungi masyarakatnya maupun sumber daya alam serta sumber daya buatan yang ada di Indonesia. Agar izin dapat diterapkan dalam kegiatan bisnis secara legal, maka perlu adanya pengaturan secara normatif dalam perundang-undangan, di mana keberadaan perundang-undangan merupakan salah satu ciri dari sistem hukum civil law sebagaimana dianut di Indonesia.

\section{Perundang-undangan Di Indonesia Dalam Mengatur Aktivitas Bisnis}

Indonesia sebagai negara yang menganut sistem hukum Civil Law tentunya memiliki karakterikstik yang sama dengan negara-negara lainnya, yaitu adanya hukum tertulis dalam mengatur masyarakat atau yang dikenal dengan perundangundangan. Di dalam sistem perundang-undangan dikenal adanya hierarkhi (tata urutan). Perundang-undangan suatu negara merupakan suatu sistem yang tidak

sebagaimana dikutip I Dewa Gede Atmadja, Ilmu Negara, Sejarah, Konsep Negara dan Kajian Kenegaraan, Malang, Setara, 2012, hlm. 84. 
menghendaki atau membenarkan atau membiarkan adanya pertentangan atau konflik peraturan didalamnya. Jika ternyata ada pertentangan yang terjadi dalam suatu sistem perundang-undangan maka salah satu dari keduanya harus ada yang dimenangkan dan ada yang dikalahkan. Oleh karena itu diperlukan asas-asas yang mengatur mengenai kedudukan masing-masing peraturan perundang-undangan, terkait dengan hal tersebut setidaknya terdapat 3 asas (adagium) dalam tata urutan peraturan perundang-undangan yang dikenal sebagai asas preferensi, yaitu:

\section{Asas lex superior derogat legi inferiori}

Terkait Asas lex superior derogat legi inferiori Kusnu Goesniadhie menyatakan, bahwa perundang-undangan yang tingkatannya lebih rendah tidak boleh bertentangan dengan peraturan perundang-undangan yang tingkatannya lebih tinggi yang mengatur materi normatif yang sama. Jika terjadi pertentangan, maka peraturan perundang-undangan yang tingkatannya lebih tinggi akan mengesampingkan peraturan perundang-undangan yang tingkatannya lebih rendah, dan karena adanya hierarki dalam peraturan perundang-undangan maka hal demikian berlaku asas lex superior derogate legi inferiori. ${ }^{2}$

\section{Asas lex posteriori derogate legi priori}

Selanjutnya terkait Asas lex superior derogat legi inferiori Kusnu Goesniadhie menyatakan, bahwa pertentangan dapat terjadi antara peraturan perundangundangan yang lama dengan peraturan perundang-undangan yang baru, yang mengatur materi normatif yang sama. Kalau diundangkan peraturan perundang-undangan yang baru dengan tidak mencabut peraturan perundangundangan yang lama yang mengatur materi yang sama sedangkan keduaduanya saling bertentangan satu sama lain, maka peraturan perundang-

2 Kusnu Goesniadhie. Harmonisasi Sistem Hukum, Mewujudkan Tata Pemerintahan Yang Baik, Malang, A3, 2010, hlm., 36. 
undangan yang baru mengesampingkan peraturan perundang-undangan yang lama, hal demikian berlaku asas lex posteriori derogate legi priori. ${ }^{3}$

3. Asas lex specialis derogate legi generali

Terkait dengan asas lex specialis derogate legi generali, Kusnu Goesniadhie menyatakan, bahwa pertentangan dapat terjadi antara peraturan perundangundangan yang bersifat umum dengan peraturan perundang-undangan yang bersifat khusus, sedangkan kedua-duanya mengatur materi normatif yang sama. Jika terjadi demikian maka peraturan perundang-undangan yang bersifat khusus akan mengesampingkan peraturan perundang-undangan yang bersifat umum, hal demikian akan berlaku asas lex specialis derogate legi generali. ${ }^{4}$

Berdasarkan Undang-Undang Nomor 12 Tahun 2011 tentang Pembentukan Peraturan Perundang-undangan, bahwa Peraturan Perundang-undangan diakui keberadaannya dan mempunyai kekuatan hukum mengikat sepanjang diperintahkan oleh Peraturan Perundang-undangan yang lebih tinggi atau dibentuk berdasarkan kewenangan. Sedangkan yang dimaksud dengan "berdasarkan kewenangan" adalah penyelenggaraan urusan tertentu pemerintahan sesuai dengan ketentuan Peraturan Perundang-undangan.

Beberapa contoh peraturan perundang-undangan yang mengatur aktivitas bisnis di Indonesia saat ini:

1. Undang-Undang Nomor 5 Tahun 1999 tentang Monopoli dan Persaingan Usaha Tidak Sehat.

Undang-Undang ini dimaksudkan untuk menegakkan aturan hukum dan memberikan perlindungan yang sama bagi setiap pelaku usaha di dalam upaya untuk menciptakan persaingan usaha yang sehat. Agar implementasi undangundang ini serta peraturan pelaksanaannya dapat berjalan efektif sesuai asas

3 Id.

4 Id., hlm., 37. 
dan tujuannya, maka perlu dibentuk Komisi Pengawas Persaingan Usaha (KPPU), yaitu lembaga independen yang terlepas dari pemerintah dan pihak lain, yang berwenang melakukan pengawasan persaingan usaha dan menjatuhkan sanksi. Sanksi tersebut berupa tindakan administratif. Secara umum, materi dari Undang-Undang Tentang Praktik Monopoli dan Persaingan Usaha Tidak Sehat mengandung 6 (enam) bagian pengaturan yang terdiri dari; perjanjian yang dilarang, kegiatan yang dilarang, posisi dominan, Komisi Pengawas Persaingan Usaha, penegakan hukum dan ketentuan lain-lain. ${ }^{5}$

2. Undang-Undang Nomor 25 Tahun 2007 tentang Penanaman Modal. Undang-undang ini memberikan jaminan perlakuan yang sama dalam rangka penanaman modal. Selain itu, undang-undang ini memerintahkan agar pemerintah meningkatkan koordinasi antar instansi pemerintah, antara instansi pemerintah dengan Bank Indonesia, dan antara instansi pemerintah dengan pemerintah daerah. Koordinasi dengan pemerintah daerah harus sejalan dengan semangat otonomi daerah. Pemerintah Daerah bersama-sama dengan instansi atau lembaga, baik swasta maupun pemerintah, harus lebih diberdayakan, baik dalam pengembangan peluang potensi daerah maupun dalam koordinasi promosi dan pelayanan penanaman modal. Pemerintah Daerah menjalankan otonomi seluas-luasnya untuk mengatur dan mengurus sendiri urusan penyelenggaraan penanaman modal berdasarkan asas otonomi daerah dan tugas pembantuan atau dekonsentrasi. Oleh karena itu, peningkatan koordinasi kelembagaan tersebut harus dapat diukur dari kecepatan pemberian perizinan dan fasilitas penanaman modal dengan biaya yang bersaing. 6

3. Peraturan Pemerintah Republik Indonesia Nomor 42 Tahun 2007 tentang Waralaba

\footnotetext{
5 Penjelasan Undang-Undang Nomor 5 Tahun 1999 tentang Monopoli dan Persaingan Usaha Tidak sehat

${ }^{6}$ Penjelasan Undang-Undang Nomor 25 Tahun 2007 tentang Penanaman Modal
} 
Dalam rangka meningkatkan pembinaan usaha dengan waralaba di seluruh Indonesia maka perlu adanya dorongan bagi pengusaha nasional terutama pengusaha kecil dan menengah untuk tumbuh sebagai Pemberi Waralaba nasional yang handal dan mempunyai daya saing di dalam negeri dan luar negeri khususnya dalam rangka memasarkan produk dalam negeri. Pemerintah memandang perlu mengetahui legalitas dan bonafiditas usaha Pemberi Waralaba dari luar negeri dan dalam negeri guna menciptakan transparansi informasi usaha yang dapat dimanfaatkan secara optimal oleh usaha nasional dalam memasarkan barang dan/atau jasa dengan waralaba. Di samping itu, pemerintah dapat memantau dan menyusun data waralaba baik jumlah maupun jenis usaha yang diwaralabakan. Untuk itu, pemberi waralaba sebelum membuat perjanjian waralaba dengan penerima waralaba harus menyampaikan prospektus penawaran waralaba kepada pemerintah dan calon penerima waralaba. Di sisi lain, apabila terjadi kesepakatan perjanjian waralaba, penerima waralaba harus menyampaikan perjanjian waralaba tersebut kepada pemerintah.7

\section{Harmonisasi Hukum Sebagai Dampak Kebijakan Berlakunya Masyarakat Ekonomi ASEAN 2015}

\section{Masyarakat Ekonomi ASEAN, Kebijakan dan Dampaknya}

Kerjasama ekonomi ASEAN dimulai dengan disahkannya Deklarasi Bangkok tahun 1967 yang bertujuan untuk mempercepat pertumbuhan ekonomi, kemajuan sosial dan pengembangan budaya. Dalam dinamika perkembangannya, kerjasama ekonomi ASEAN diarahkan pada pembentukan Komunitas Ekonomi ASEAN (ASEAN Economic Community) yang pelaksanaannya berjalan relatif lebih

\footnotetext{
7 Penjelasan Peraturan Pemerintah Nomor 42 Tahun 2007 tentang Waralaba
} 
cepat dibandingkan dengan kerjasama di bidang politik-keamanan dan sosial budaya. 8

Diawali pada Konferensi Tingkat Tinggi (KTT) ASEAN ke-2 tanggal 15 Desember 1997 di Kuala Lumpur, Malaysia, dengan disepakatinya Visi ASEAN 2020, para Kepala Negara ASEAN menegaskan bahwa ASEAN akan:

a. menciptakan Kawasan Ekonomi ASEAN yang stabil, makmur dan memiliki daya saing tinggi yang ditandai dengan arus lalu lintas barang, jasa-jasa dan investasi yang bebas, arus lalu lintas modal yang lebih bebas, pembangunan ekonomi yang merata serta mengurangi kemiskinan dan kesenjangan sosialekonomi;

b. mempercepat liberalisasi perdagangan di bidang jasa, dan

c. meningkatkan pergerakan tenaga professional dan jasa lainnya secara bebas di kawasan. Selanjutnya pada beberapa KTT berikutnya (KTT ke-6, ke-7) para pemimpin ASEAN menyepakati berbagai langkah yang tujuannya adalah untuk mewujudkan visi tersebut. ${ }^{9}$

Pada KTT ASEAN Ke-12, para pemimpin ASEAN menegaskan komitmen yang kuat untuk mempercepat pembentukan Komunitas ASEAN pada tahun 2015 sejalan dengan Visi ASEAN 2020 dan BALI CONCORD II, dan menandatangani Cebu Declaration on Acceleration of the establishment of an ASEAN Community by 2015. Secara khusus, para pemimpin sepakat untuk mempercepat pembentukan Komunitas Ekonomi ASEAN (KEA) pada tahun 2015 dan mentransformasikan kawasan ASEAN menjadi suatu kawasan di mana terdapat aliran bebas barang, jasa, investasi, dan tenaga kerja terampil, serta aliran modal yang lebih bebas. ${ }^{10}$

8 http://www.smecda.com/Files/Asean/Buku Menuju ASEAN Economic Community 2015, 13 Agustus 2015, 10:30.

9 Id.

10 http://www.smecda.com/Files/Asean/Cetak Biru Komunitas Ekonomi ASEAN. Pdf, 13 Agustus 2015, 10:13. 
KEA akan membentuk ASEAN sebagai suatu pasar tunggal dan basis produksi serta menjadikan ASEAN lebih dinamis dan kompetitif dengan langkahlangkah dan mekanisme baru untuk memperkuat implementasi inisiatif-inisiatif ekonomi yang telah ada; mempercepat integrasi kawasan dalam sektor-sektor prioritas; mempermudah pergerakan para pelaku usaha tenaga kerja terampil dan berbakat dan memperkuat mekanisme institusi ASEAN. Sebagai langkah awal menuju KEA, ASEAN telah mengimplementasikan berbagai rekomendasi High Level Task Force (HLTF) on ASEAN Economic Integration sebagaimana tertera dalam Bali Concord.

Gambaran karakteristik utama MEA adalah pasar tunggal dan basis produksi; kawasan ekonomi yang berdaya saing tinggi; kawasan dengan pembangunan ekonomi yang adil; dan kawasan yang terintegrasi ke dalam ekonomi global. Dampak terciptanya MEA adalah terciptanya pasar bebas di bidang permodalan, barang dan jasa, serta tenaga kerja. Konsekuensi atas kesepakatan MEA yakni dampak aliran bebas barang bagi negara-negara ASEAN, dampak arus bebas jasa, dampak arus bebas investasi, dampak arus tenaga kerja terampil, dan dampak arus bebas modal. Dari karakter dan dampak MEA tersebut di atas sebenarnya ada peluang dari momentum MEA yang bisa diraih Indonesia. Dengan adanya MEA diharapkan perekonomian Indonesia menjadi lebih baik. Salah satunya pemasaran barang dan jasa dari Indonesia dapat memperluas jangkauan ke negara ASEAN lainnya. Pangsa pasar yang ada di Indonesia adalah 250 juta orang. Pada MEA, pangsa pasar ASEAN sejumlah 625 juta orang bisa disasar oleh Indonesia. Jadi, Indonesia memiliki kesempatan lebih luas untuk memasuki pasar yang lebih luas. Ekspor dan impor juga dapat dilakukan dengan biaya yang lebih murah. Tenaga kerja dari negara-negara lain di ASEAN bisa bebas 
bekerja di Indonesia. Sebaliknya, tenaga kerja Indonesia (TKI) juga bisa bebas bekerja di negara-negara lain di ASEAN. ${ }^{11}$

Dampak Positif lainnya yaitu investor Indonesia dapat memperluas ruang investasinya tanpa ada batasan ruang antar negara anggota ASEAN. Begitu pula kita dapat menarik investasi dari para pemodal-pemodal ASEAN. Para pengusaha akan semakin kreatif karena persaingan yang ketat dan para professional akan semakin meningkatkan skill, kompetensi dan profesionalitas yang dimilikinya. ${ }^{12}$

Namun, selain peluang yang terlihat di depan mata, ada pula hambatan menghadapi MEA yang harus kita perhatikan. Hambatan tersebut diantaranya: pertama, mutu pendidikan tenaga kerja masih rendah, di mana hingga Febuari 2014 jumlah pekerja berpendidikan SMP atau dibawahnya tercatat sebanyak 76,4 juta orang atau sekitar 64 persen dari total 118 juta pekerja di Indonesia. Kedua, ketersediaan dan kualitas infrastruktur masih kurang sehingga mempengaruhi kelancaran arus barang dan jasa. Menurut Global Competitiveness Index (GCI) 2014, kualitas infrastruktur kita masih tertinggal dibandingkan negara Singapura, Malaysia, Brunei Darussalam dan Thailand. Ketiga, sektor industri yang rapuh karena ketergantungan impor bahan baku dan setengah jadi. Keempat, keterbatasan pasokan energi. Kelima, lemahnya Indonesia menghadapi serbuan impor, dan sekarang produk impor Tiongkok sudah membanjiri Indonesia. Apabila hambatan-hambatan tadi tidak diatasi maka dikhawatirkan MEA justru akan menjadi ancaman bagi Indonesia. ${ }^{13}$

\section{Harmonisasi Peraturan Perundang-undangan di Indonesia}

Berdasarkan gambaran di atas, maka salah satu yang perlu dilakukan adalah harmonisasi hukum dalam melaksanakan kebijakan MEA. Di Indonesia

\footnotetext{
11 http://www.bppk.kemenkeu.go.id/publikasi/artikel/150-artikel-keuangan-umum/20545masyarakat-ekonomi-asean-mea-dan-perekonomian-indonesia, 16 Juni 2015, 02:30.

12 Id.

13 Id.
} 
dalam konteks harmonisasi hukum, dapat diketahui dalam Pasal 2 Keputusan Presiden Nomor 188 Tahun 1998 yang berbunyi:

"Dalam rangka pengharmonisasian, pembulatan dan pemantapan konsepsi yang akan dituangkan dalam Rancangan Undang-Undang, Menteri atau pimpinan lembaga pemrakarsa penyusun Rancangan Undang-Undang wajib mengkalkulasikan terlebih dahulu konsepsi tersebut dengan Menteri kehakiman dan Menteri serta Pimpinan Lembaga lainnya yang terkait."

Menurut L.M Gandhi, harmonisasi dalam hukum adalah mencakup penyesuaian peraturan perundang-undangan, keputusan pemerintah, keputusan hakim, sistem hukum dan asas-asas hukum dengan tujuan peningkatan kesatuan hukum, kepastian hukum, keadilan dan kesebandingan, kegunaan dan kejelasan hukum, tanpa mengaburkan dan mengorbankan pluralisme hukum. ${ }^{14}$

Tanpa adanya harmonisasi sistem hukum akan memunculkan keadaan tidak adanya jaminan kepastian hukum yang dapat menimbulkan gangguan dalam kehidupan bermasyarakat, ketidaktertiban dan rasa tidak dilindungi. Dalam perspektif demikian, masalah kepastian hukum akan dirasakan sebagai kebutuhan yang hanya terwujud melalui harmonisasi sistem hukum. ${ }^{15}$

Dengan demikian, harmonisasi sistem hukum internasional adalah pengharmonisasian pluralitas sistem hukum dalam sistem hukum internasional, untuk membentuk uniformitas sistem hukum yang dapat disetujui dan diterima oleh semua negara dalam melaksanakan transaksi-transaksi perdagangan internasional. Dirumuskan dalam dalam dua langkah yaitu penyesuaian sistem hukum nasional menjadi sistem hukum yang bersifat global, dan dengan demikian yang harmonis dan seragam adalah hukum positifnya (harmony of law) dan

14 LM. Gandhi, Harmonisasi Hukum Menuju Hukum Yang Responsif, Makalah yang disampaikan pada Pidato Pengukuhan Guru Besar Tetap FH-UI, 1995, dalam Moh. Hasan Wargakusumah. Perumusan Harmonisasi Hukum Tentang Metodologi Harmonisasi Hukum. Jakarta, BPHN, Depkumham, 1996, hlm., 28-29.

15 Kusnu Goesnadhie, Harmonisasi Hukum Dalam Perspektif Perundang-undangan; Lex Specialis Suatu Masalah, Surabaya, JP Books, 2006, hlm., 100. 
penyesuaian norma-norma hukum tertentu menjadi satu kesatuan norma yang bersifat global yang kelak dapat digunakan sebagai sarana penyelesaian sengketa, dengan demikian yang harmonis dan seragam adalah keputusan-keputusan hakim. ${ }^{16}$

Perumusan langkah yang ideal yang ditempuh dalam harmonisasi sistem hukum adalah sebagaimana dikemukakan oleh L. Friedmann yaitu perlu melakukan penyesuaian unsur-unsur tatanan hukum yang berlaku dalam kerangka sistem hukum nasional (legal system) yang mencakup komponen materi hukum (legal substance), komponen struktur hukum beserta kelembagaannya (legal structure) dan komponen budaya hukum (legal culture). Dengan demikian harmonisasi sistem hukum nasional melibatkan mata rantai hubungan ketiga komponen sistem hukum tersebut dalam kerangka sistem hukum nasional. ${ }^{17}$

Selanjutnya memperhatikan sistem hukum nasional sebagai masukan, yaitu memperhitungkan keberadaan sistem hukum nasional yang sedang berjalan (existing legal system), yang menyangkut unsur-unsur substansi hukum, tata hukum yang terdiri tatanan hukum eksternal yaitu peraturan perundangundangan, hukum tidak tertulis termasuk hukum adat dan yurisprudensi serta tatanan hukum internal yaitu asas-asas hukum yang melandasinya, struktur hukum beserta kelembagaannya (legal structure), yang terdiri atas berbagai badan institusional atau kelembagaan publik dengan para pejabatnya. ${ }^{18}$

Namun demikian, sebagai negara yang berdaulat, sistem hukum di Indonesia harus memiliki proteksi dari dampak negatif globalisasi. Sistem hukum ekonomi Indonesia harus berpihak kepada ekonomi rakyat sebagaimana yang ditegaskan dalam konstitusi, yakni pasal 33 Undang-Undang Dasar 1945 dan

16 Id., hlm., 107.

17 Id., hlm., 84-85.

18 Id. 
bukan mengabdi kepada sistem ekonomi kapitalis yang mengkultuskan pasar bebas. ${ }^{19}$

\section{Izin Sebagai Instrumen Penting Dalam Kegiatan Bisnis Pada Era Masyarakat Ekonomi ASEAN 2015}

\section{Pengertian Izin}

Izin adalah suatu instrumen pemerintahan yang bersifat yuridis preventif, yang digunakan sebagai sarana hukum administrasi untuk mengendalikan perilaku masyarakat. Ini berarti izin hanya dapat diterbitkan atau dikeluarkan oleh pemerintah saja sebagai badan hukum publik, tidak dapat diterbitkan oleh pihak swasta maupun perorangan. Tidak ada delegasi atau mandat apalagi atribusi kewenangan penerbitan izin kepada badan hukum swasta maupun perorangan.

Kewenangan administrasi negara dalam menjalankan pemerintahan bisa didapatkan secara atribusi, delegasi, dan mandat. Di dalam praktik, ketiga hal tersebut dilaksanakan secara kombinasi, yang bertalian erat dengan asas-asas desentralisasi, dekonsentrasi dan tugas pembantuan, serta dalam operasionalnya berbaur satu sama lain, dengan syarat harus seimbang, serasi dan selaras.

Dari hasil penelusuran, ketentuan perundang-undangan tentang penyelenggaraan pemerintahan, terdapat aneka ragam administrasi negara pemberi izin yang didasarkan kepada jabatan yang diembannya, baik di tingkat pusat maupun daerah. Dengan demikian dapat diketahui bahwa lembaga yang berwenang memberikan izin dimulai dari administrasi negara tertinggi sampai administrasi negara yang terendah. Karena beraneka ragam lembaga yang berwenang memberi izin, baik secara vertikal maupun horizontal, maka terdapat

\footnotetext{
${ }^{19}$ Rosyidi Hamzah, Peranan Hukum Dalam Menghadapi Pemberlakuan Asean Economic Community Di Indonesia, Prosiding Seminar Nasional Kesiapan Indonesia: Harmonisasi Hukum Negara-Negara ASEAN Menuju Komunitas Asean 2015, Surakarta, Fakultas Hukum Universitas Muhamadiyah Surakarta, hlm., 464.
} 
pula berbagai macam instrumen hukum dalam rangka mengaplikasikannya dalam kehidupan bermasyarakat di semua sektor yang beraneka ragam tersebut.

Sejalan dengan diberlakukannya Undang-Undang Nomor 23 Tahun 2014 tentang Pemerintahan Daerah, di mana daerah diberikan kebebasan untuk menyelenggarakan urusan rumah tangganya sendiri, maka izin oleh pemerintah daerah dijadikan sebagai salah satu pendapatan daerah guna membiayai jalannya pemerintahan. Dengan adanya kondisi tersebut, maka pemerintah daerah perlu memberlakukan suatu ketentuan perizinan. Hal ini diadakan selain untuk menambah penghasilan daerah, juga dimaksudkan agar terjadinya suatu tertib administrasi dalam melaksanakan pembangunan di daerah

\section{Tujuan dan Fungsi Izin}

a) Izin itu digunakan sebagai sarana hukum administrasi karena izin itu bersifat hukum publik (bukan perdata namun juga bukan pidana) yang terkait dengan kepentingan umum, sepihak dan mengikat, sehingga apabila timbul sengketa hukum dari perizinan maka penyelesaiannya dilakukan di Pengadilan Tata Usaha Negara (PTUN).

b) Hal yang sangat penting adalah bahwa izin itu digunakan sebagai sarana yuridis untuk mengendalikan perilaku masyarakat.

c) Untuk itu, agar izin tidak melanggar hak-hak asasi manusia, maka setiap izin itu harus memenuhi asas legalitas.

d) Dengan demikian, tindak pemerintahan (bestuurshandeling) yang berkaitan langsung dengan fungsi mengendalikan (controle) masyarakat adalah izin (vergunning).

e) Izin merupakan bentuk ketentuan yang memperbolehkan atau memperkenankan menurut hukum (sarana pengabsahan atau legitimasi yuridis) bagi seseorang untuk melakukan sesuatu sesuai dengan jenis izin yang diterima. 
f) Di dalam suatu izin dapat dicantumkan persyaratan tertentu yang harus dipatuhi oleh pemegang izin, dan apabila pemegang izin tersebut terbukti melanggar persyaratan yang telah ditetapkan, maka pejabat pemberi izin berwenang mencabut izin tersebut.

g) Dengan fungsinya yang demikian maka sistem perizinan merupakan sarana untuk mengendalikan kegiatan masyarakat. Ini berarti pemerintah berwenang untuk mengatur, mengarahkan, mengemudikan dan sekaligus pula melindungi masyarakat maupun sumber daya alam dan sumber daya buatan.

Sehingga bisa dikatakan bahwa unsur/fungsi dari izin terdiri dari:

a) Instrumen pemerintahan

Pada prinsipnya pemberi izin adalah pihak yang berwenang mencabut izin. Konsekuensinya apabila pemegang izin tersebut terbukti melanggar persyaratan yang telah ditetapkan, maka pejabat pemberi izin berwenang mencabut izin tersebut. Ini berarti pemerintah berwenang untuk mengatur, mengarahkan, mengemudikan dan sekaligus pula melindungi masyarakat maupun sumber daya alam dan sumber daya buatan.

Tujuan dari izin sebagai instrumen pemerintah dalam rangka mengatur, mengarahkan, mengemudikan dan sekaligus pula melindungi masyarakat maupun sumber daya alam dan sumber daya buatan adalah sebagai berikut:

1) Mengkonkretkan norma umum pada perbuatan hukum tertentu;

2) Mengatur pada perbuatan individual;

3) Memberikan perlindungan hukum;

4) Melindungi kepentingan umum, barang publik, benda cagar budaya, dan lingkungan hidup.

b) Yuridis preventif

Izin adalah suatu instrumen pemerintahan yang bersifat yuridis preventif, yang digunakan sebagai sarana hukum administrasi untuk mengendalikan perilaku masyarakat. Tindakan preventif adalah tindakan atau mekanisme di 
mana satu kejadian yang tidak diharapkan dicegah terjadinya melalui pengaturan prosedur pelaksanaan kegiatan, baik yang bersifat keharusan maupun sukarela. ${ }^{20}$ Izin itu bersifat yuridis preventif karena di dalam izin dimuat norma larangan dan atau norma perintah yang wajib ditaati oleh pemegang izin.

c) Sarana hukum administrasi

Izin adalah suatu keputusan administrasi negara yang memperkenankan suatu perbuatan yang pada umumnya dilarang, tetapi diperkenankan dan bersifat konkret. ${ }^{21}$ Pernyataan ini didukung oleh Ateng Syafrudin yang mengatakan bahwa izin bertujuan untuk menghilangkan halangan, di mana hal yang dilarang menjadi diperbolehkan. ${ }^{22}$

Jadi dapat dikatakan bahwa izin itu adalah merupakan perangkat hukum administrasi yang digunakan oleh pemerintah untuk mengendalikan warganya dalam hal terdapat kegiatan yang bisa dikatakan tidak diperkenankan, dengan syarat-syarat tertentu hal tersebut dapat diperbolehkan.

d) Pengendalian (controle) perilaku masyarakat

Izin dalam pengelolaan lingkungan hidup dimaksudkan agar suatu kegiatan yang berkaitan pengelolaan lingkungan hidup tidak sampai menimbulkan kerusakan terhadap ekosistem yang ada.

Pemerintah Indonesia telah mensahkan Undang-Undang Nomor 25 Tahun 2007 tentang Penanaman Modal yang menyiratkan bahwa harus diadakan reformasi perizinan menuju pelayanan terpadu satu pintu (one stop service). Dasar dari kebijakan itu adalah untuk memberikan kemudahan proses perizinan dan

20 PPLH UGM, CEPI UCE, Panduan Untuk Fasilitator - Penaatan, Pengendalian, Penegakan Hukum dan Pengaturan, Jakarta, 2001, hlm., 48.

21 Jaja Ahmad Jayus, Lembaga Perizinan Sebagai Sarana Pengendalian Investasi Dalam Implementasi Otonomi Daerah, Tesis Program Pascasarjana Universitas Katolik Parahyangan, Bandung, 2001, hlm., 100.

22 Ateng Syafrudin, Perizinan Untuk Kegiatan Tertentu, Majalah Hukum Media Komunikasi FHUnpas, Edisi 23, Tahun 1997, hlm., 5. 
memberikan kepastian hukum, kepastian berusaha, dan keamanan berusaha bagi penanaman modal sejak proses pengurusan perizinan sampai dengan berakhirnya kegiatan penanaman modal sesuai dengan ketentuan peraturan perundangundangan.

Undang-undang Nomor 23 Tahun 2014 tentang Pemerintahan Daerah juga telah mengakomodir bahwa pemerintah daerah wajib membentuk unit pelayanan terpadu satu pintu dalam memberikan pengesahan dan pelayanan perizinan sesuai dengan ketentuan peraturan perundang-undangan. Pelayanan perizinan terpadu merupakan kegiatan penyelenggaraan perizinan yang proses pengelolaannya mulai dari tahap permohonan sampai dengan tahap terbitnya dokumen, dilakukan dalam satu tempat. Jadi dengan diselenggarakannya sistem pelayanan perizinan terpadu satu pintu diharapkan bahwa pelayanan terpadu di pusat dan di daerah dapat menciptakan penyederhanaan perizinan dan percepatan penyelesaiannya demi terwujudnya tujuan reformasi birokrasi pelayanan perizinan. Reformasi pelayanan perizinan idealnya menggunakan prinsip kesederhanaan, keseragaman aturan yang berlaku secara nasional seperti tentang kejelasan prosedur dan biaya, kepastian waktu, kemudahan akses, kenyamanan, kedisiplinan, dan keramahan dari petugasnya.

Perizinan merupakan bagian terpenting dalam investasi, khususnya dalam kerangka MEA. Namun, aspek birokrasi dapat menjadi penghambat iklim investasi bila masih terdapat hal-hal seperti banyaknya peraturan yang tumpang tindih atau kontradiksi, prosedur berbelit-belit, tingginya biaya, tidak adanya jangka waktu penyelesaian, sarana dan prasarana yang tidak memadai serta kinerja petugas yang tidak efektif dan efisien. Sehingga diperlukan penataan birokrasi sebagai wujud reformasi perizinan, yang mana penataan tersebut dilakukan upaya penyusunan, pengaturan, penertiban, pengarahan, secara sistematis pengaturan perizinan menurut peraturan perundang-undangannya. 


\section{Penutup}

Perizinan merupakan bagian terpenting dalam investasi yang digunakan sebagai sarana hukum administrasi untuk mengendalikan perilaku masyarakat. Instrumen izin menunjukkan bahwa masing-masing negara tetap memiliki otoritas dan kedaulatan yang kuat dalam melaksanakan jurisdiksinya terkait pengendalian dan pengawasan kegiatan bisnis. Namun aspek birokrasi dapat menjadi penghambat iklim investasi apabila masih terdapat hal-hal seperti banyaknya peraturan yang tumpang tindih atau kontradiksi dan prosedur yang berbelit-belit. Untuk itu diperlukan penataan birokrasi sebagai wujud reformasi perizinan, yang mana penataan tersebut dilakukan melalui upaya penyusunan, pengaturan, penertiban, pengarahan, secara sistematis pengaturan perizinan menurut peraturan perundang-undangannya.

\section{Daftar Pustaka}

Buku:

Kusnu Goesniadhie, Harmonisasi Hukum Dalam Perspektif Perundang-undangan; Lex Specialis Suatu Masalah, Surabaya, JP Books, 2006.

Harmonisasi Sistem Hukum, Mewujudkan Tata Pemerintahan Yang Baik, A3, Malang, 2010.

I Dewa Gede Atmadja, Ilmu Negara, Sejarah, Konsep Negara dan Kajian Kenegaraan, Setara, Malang, 2012.

Peter de Cruz, Perbandingan Sistem Hukum, Common Law, Civil Law And Socialist Law, Nusa Media, Bandung, 2014.

PPLH UGM, CEPI UCE, Panduan Untuk Fasilitator-Penaatan, Pengendalian, Penegakan Hukum dan Pengaturan, Jakarta, 2001.

\section{Jurnal/Prosiding/Makalah}

Ateng Syafrudin, Perizinan Untuk Kegiatan Tertentu, Majalah Hukum Media Komunikasi FH-Unpas, Edisi 23, Tahun 1997.

LM. Gandhi. Harmonisasi Hukum Menuju Hukum Yang Responsif. Makalah yang disampaikan pada Pidato Pengukuhan Guru Besar Tetap FH-UI, 1995, dalam Moh. Hasan Wargakusumah. Perumusan Harmonisasi Hukum Tentang Metodologi Harmonisasi Hukum. Jakarta: BPHN, Depkumham, 1996. 
Rosyidi Hamzah, Peranan Hukum Dalam Menghadapi Pemberlakuan ASEAN Economic Community Di Indonesia. Prosiding Seminar Nasional Kesiapan Indonesia: Harmonisasi Hukum Negara-Negara ASEAN Menuju Komunitas ASEAN 2015. Surakarta: Fakultas Hukum Universitas Muhamadiyah Surakarta.

\section{Tesis}

Jaja Ahmad Jayus, Lembaga Perizinan Sebagai Sarana Pengendalian Investasi Dalam Implementasi Otonomi Daerah, Tesis Program Pascasarjana Universitas Katolik Parahyangan, Bandung, 2001.

\section{Perundang-undangan}

Undang-Undang Nomor 5 Tahun 1999 tentang Monopoli dan Persaingan Usaha Tidak Sehat.

Undang-Undang Nomor 25 Tahun 2007 tentang Penanaman Modal.

Undang-Undang Nomor 23 Tahun 2014 tentang Pemerintahan Daerah.

Peraturan Pemerintah Republik Indonesia Nomor 42 Tahun 2007 tentang Waralaba.

\section{Internet}

http://www.bppk.kemenkeu.go.id/publikasi/artikel/150-artikel-keuangan umum/20545-masyarakat-ekonomi-ASEAN-mea-dan-perekonomianindonesia. 16 Juni 2015.

http://www.gresnews.com/berita/tips/4292810-perbandingan-civil-law-dancommon-law. 29 Juni 2015.

http://www.smecda.com/Files/ASEAN/Buku Menuju ASEAN ECONOMIC COMMUNITY 2015. 13 Agustus 2015. 